\title{
Mirosława Siuciak, Kształtowanie się kategorii gramatycznej liczebnika w języku polskim, Wydawnictwo Uniwersytetu Śląskiego, Katowice 2008, ss. 234
}

Rozprawa Mirosławy Siuciak sytuuje się w nurcie jej badań nad ewolucją systemu gramatycznego polszczyzny, stanowi zwieńczenie jej dociekań dotyczących rozwoju „stosunkowo młodej” kategorii gramatycznej liczebnika, kształtującej się w ciagu czterech stuleci, od XVI do XX wieku. Jak deklaruje autorka, celem jej rozprawy jest „dokładne zbadanie procesu historycznojęzykowego, w wyniku którego z kilku klas leksemów pełniących funkcję kwantyfikatorów numerycznych ukształtowała się wspólna kategoria [...]" (s. 7). Przyjęła teoretyczno-metodologiczne założenia strukturalizmu, co uzasadnia następująco: „Opis rozciagającego się na cztery stulecia procesu wymaga strukturalnego spojrzenia na język, w którym wszelkie zmiany wzajemnie się warunkują. Nie jest bowiem przypadkiem, że przekształcenia w zakresie funkcjonowania liczebników w polszczyźnie przybierają na sile w XVI i XVII wieku, kiedy system deklinacyjny znajduje się w fazie intensywnych przeobrażeń, związanych z zanikiem liczby podwójnej, przebudową i normalizacją systemu fleksyjnego rzeczowników [...] oraz ustalaniem się nowych opozycji rodzajowych w liczbie mnogiej" (s. 21).

W szczególności odwołuje się Mirosława Siuciak do koncepcji strukturalnej interpretacji historii języka autorstwa Ireny Bajerowej. Istotą tej koncepcji jest założenie teleologicznego charakteru zmian językowych, samorzutnie zmierzających do normalizacji oraz optymalizacji funkcji i wyrazistości formalnej, ,polegającej na samoistnej likwidacji wariantywności i rozchwiania normy" (s. 22). W płaszczyźnie uwarunkowanego koncepcjami teoretycznymi praktycznego instrumentarium badawczego autorka przyjęła zaproponowaną przez Irenę Bajerowa, a rozwinięta przez Wojciecha Ryszarda Rzepkę metodę przekrojów synchronicznych: „Polega ona na drobiazgowym odtworzeniu 
przebiegu procesu historycznojęzykowego od momentu wyjściowego (czyli pojawienia się nowego wariantu jako neologizmu) aż do fazy końcowej, w której zmiana systemu już się dokonała, a stare formy funkcjonują na zasadzie archaizmu. Wskazanie etapów przełomowych staje się możliwe dzięki wydzieleniu pośrednich odcinków czasowych, reprezentowanych przez proporcjonalnie dobrane źródła, na podstawie których przy zastosowaniu metod statystycznych można śledzić intensywność zachodzenia zmiany językowej. Dopiero dokładne zbadanie udziału konkurujących ze sobą w danym wycinku synchronicznym wariantów oraz zestawienie wyników z poszczególnych okresów dają pełny obraz tempa i dynamiki procesów rozwojowych" (s. 23).

Ze względu na warunki obiektywne (niewielka, a w pierwszych dziesięcioleciach praktycznie zerowa, liczba tekstów drukowanych w pierwszej połowie XVI wieku), a także konieczność dostosowania się do segmentacji przyjętej w monografii polszczyzny XVII wieku (Urszula Burzywoda, Danuta Ostaszewska, Artur Rejter, Mirosława Siuciak, Polszczyzna XVII wieku. Stan i przeobrażenia, Katowice 2002), ostatecznie Mirosława Siuciak przyjęła niezupełnie symetryczny dla poszczególnych wieków układ czternastu okresów synchronicznych, oznaczonych osobno dla każdego stulecia: 1520-1535 (16 $\left.{ }^{\mathrm{I}}\right), 1550-1565$ (16 $\left.{ }^{\mathrm{II}}\right)$, 1575-1585 (16 $\left.{ }^{\mathrm{III}}\right), 1600-1610$ (17 I $), 1630-1640$ (17 II), 1660-1670 (17 $\left.{ }^{\mathrm{III}}\right)$, 1690-1700 (17 IV $), 1720-1730$ (18 I $), 1750-1760$ (18 II), 1780-1790 (18 $\left.{ }^{\mathrm{III}}\right)$, 1810-1820 (19 I ), 1840-1850 (19 II), 1870-1880 (19 $\left.{ }^{\mathrm{III}}\right)$ i 1900-1910 (20 I).

Podstawę materiałową rozprawy stanowią druki wydane w tych okresach, „zazwyczaj pierwsze wydania (chociaż zdarzają się też późniejsze wznowienia), w nielicznych wypadkach wykorzystane zostały krytyczne edycje dzieł dawnych" (s. 26). Najpoważniejszy problem stanowiła dla autorki rzadkość form liczebnikowych w tekstach (,liczebniki należą do leksemów o niskiej frekwencji - zdarza się, że w dwustustronicowym tekście występuje zaledwie kilka form liczebnikowych”, s. 26). Ponadto od XVIII wieku nasila się „,maniera wyrażania stosunków ilościowych za pomocą oznaczeń cyfrowych” (s. 26), zwłaszcza w wypadku liczebników określających wyższe wartości liczbowe. Wszystko to spowodowało, że badaczka - co trzeba uznać za postępowanie ze wszech miar słuszne i uzasadnione - musiała elastycznie traktować przedziały czasowe (,jeżeli spotkałam tekst niemieszczący się w wyznaczonych okresach, a zawierał on dużą liczbę interesujących mnie przykładów, to włączałam go do kanonu", s. 27) i zasadę proporcjonalności objętościowej, gatunkowej i geograficznej w doborze źródeł. Zasadne jest też stanowisko autorki w kwestii konfrontacji empirycznego materiału językowego z normą teoretyczną: „W związku z tym, że proces będący przedmiotem analizy [...] przebiegał zasadniczo w ciagu czterech stuleci, z których dopiero w ostatnim zmiany zachodziły w warunkach istnienia normy teoretycznej, podstawą wnioskowania będą 
przykłady uzyskane głównie z materiałów źródłowych. Odwołanie do normy teoretycznej oraz do funkcjonujących $\mathrm{w}$ dobie średniopolskiej podręczników dla cudzoziemców będzie miało wyłącznie charakter pomocniczy, służący jedynie konfrontacji z wynikami analiz materiałowych" (s. 29).

O wartości rozprawy Mirosławy Siuciak stanowią - moim zdaniem przede wszystkim następujące aspekty i elementy:

1. Waga podjętej w pracy problematyki. Analityczno-syntetyczne opracowanie rozwoju kategorii gramatycznej (części mowy) w historii języka polskiego to bardzo ambitne przedsięwzięcie badawcze. O randze tego rodzaju opracowań najlepiej świadczy format poprzedników autorki na tym polu badawczym: jednego z największych polskich językoznawców, Zenona Klemensiewicza, i wybitnego slawisty i polonisty francuskiego, Henriego Grappina.

2. Bogactwo materiału językowego. Został on wyekscerpowany z bardzo obszernego zestawu źródeł, który sama autorka tak charakteryzuje: „Podstawowy kanon źródeł liczy 250 druków (zazwyczaj obszernych, kilkusetstronicowych), czyli na każdy okres przypada około 16-23 tekstów. Zdarza się też, że kanon był poszerzany o druki krótsze, z których wyekscerpowano zaledwie kilka, kilkanaście form, dlatego też nie zostały ujęte w wykazie źródeł" (s. 27).

3. Imponujące zaplecze erudycyjne rozprawy. Spis literatury przedmiotu (s. 219-228) obejmuje ponad 190 pozycji (w językach: polskim, angielskim, francuskim, niemieckim, łacińskim, rosyjskim i czeskim), z czego prawie połowa (89 pozycji) to książki, nierzadko bardzo obszerne. Warto przy tym podkreślić, że nie chodzi tu bynajmniej o erudycyjny popis: znajomość rozległej literatury przedmiotu ma charakter „sfunkcjonalizowany”, jej wyniki, umiejętnie wyzyskane przez autorkę, są obecne i widoczne w tekście jej pracy, która dzięki temu zyskuje na głębi i gruntowności.

4. Samoistna wartość informacyjna części wstępnej, w której autorka wzorowo (gdyż bardzo zwięźle, a równocześnie wyczerpująco, ponadto w sposób przejrzysty, uporządkowany i sproblematyzowany) przedstawiła historię i zakres użycia terminu „,liczebnik”, współczesną sytuację liczebnika jako kategorii gramatycznej w ujęciu różnych uczonych i szkół lingwistycznych oraz rozwój liczebników od okresu wspólnoty prasłowiańskiej (z ekskursami w przeszłość indoeuropejską) do okresu rozpadu tej wspólnoty i narodzin polszczyzny jako odrębnego języka słowiańskiego.

5. Gruntowność, wielostronność i wnikliwość analizy i interpretacji. Całość niezwykle złożonego procesu gramatykalizacji kategorii liczebnika w języku polskim autorka ujęła $\mathrm{w}$ precyzyjny i głęboko przemyślany układ procesów redukcyjnych z jednej, a unifikacyjnych z drugiej strony, a w ramach obu tych głównych tendencji usytuowała skorelowane ze sobą i współzależne od siebie zjawiska fleksyjne i składniowe. 
6. Bardzo ważne i interesujące wyniki naukowe (jako skutek wszystkich wyliczonych wyżej walorów). Niepodobna tu wymienić wszystkich, zwłaszcza licznych szczegółowych. Ograniczę się do przykładowego wskazania kilku spośród (moim zdaniem) najciekawszych i najważniejszych:

a. Przekonujące wykazanie, że proces kształtowania się kategorii gramatycznej liczebnika przebiegał etapami, „których punktem wyjściowym były zawsze zmiany zachodzące $\mathrm{w}$ obrębie jednostek o najniższej wartości liczbowej (2-4), a na końcu każdego procesu wyrównawczego znajdowały się formacje o wartościach najwyższych (500-900). Przy opisie poszczególnych zjawisk uderzającą staje się konstatacja, że zasadnicze przeobrażenia w obrębie liczebników były przeprowadzane zgodnie z kolejnością wynikająca z wartości liczbowej" (s. 199).

b. Ustalenie, że rolę swoistego katalizatora, uruchamiającego procesy unifikacyjne (w których wyniku jedenaście odziedziczonych z prasłowiańszczyzny typów odmiany liczebników zostało zredukowanych do jednolitej odmiany liczebników 5-900, czemu towarzyszyło znaczne ujednolicenie zachowań składniowych; odrębność fleksyjną i syntaktyczną zachowały tylko liczebniki 2-4), odegrał zanik liczby podwójnej, co zdaniem autorki „,stworzyło warunki do formalnego zbliżenia nie tylko między leksemem $d w a$ i najbliższymi mu w ciagu arytmetycznym jednostkami trzy, cztery (także nieokreślonym kilka), ale też między zbudowanymi na bazie $d w a$ leksemami 12, 20, 200 i pobliskimi $13,14,30,40,300,400$ ” (s. 200).

c. Ustalenie, że podobną rolę katalizatora odegrał w kształtowaniu się kategorii gramatycznej liczebnika proces narodzin i morfologizacji rodzaju męskoosobowego w liczbie mnogiej.

d. Najogólniejszy wniosek: „Spojrzenie na liczebniki z perspektywy diachronicznej z uwzględnieniem wszystkich meandrów wielopoziomowego rozwoju pozwala zrozumieć, dlaczego jest to współcześnie kategoria tak bardzo skomplikowana, budząca wiele kontrowersji (szczególnie w opisie syntaktycznym) i prowokująca różne stanowiska badawcze. [...] proces gramatykalizacji tej klasy nie został jeszcze zakończony. Podsumowaniem charakterystyki kategorii liczebnika we współczesnej polszczyźnie może być stwierdzenie [...]: W odróżnieniu od innych części mowy, liczebnik zaskakuje nas brakiem konsekwencji w zachowaniu, czyli różnorodnością ostatecznych rozwiązań, co należy uznać za syntezę jego opisu gramatycznego" (s. 203).

Wyliczone wyżej zalety i wyniki naukowe przesądzają o tym, że rozprawa Mirosławy Siuciak należy do najważniejszych i najlepszych monografii historycznojęzykowych ostatnich lat. 